\section{BRAZILIAN ARCHIVES OF BIOLOGY AND TECHNOLOGY}

A N INTERNATIONAL JOURNAL

\title{
Fetal Mummification in Silky Shark (Carcharhinus falciformis) from the Gulf of California, Mexico
}

\author{
Jonathan Sandoval-Castillo $^{\mathbf{1}^{*}}$ and Carlos Villavicencio-Garayzar ${ }^{2}$ \\ ${ }^{I}$ Departamento de Oceanografía Biológica; CICESE; Km 107; Tijuana-Ensenada; C. P.: 22860; \\ sandoval@cicese.mx; Ensenada; BC. Mexico. ${ }^{2}$ Lab. Elasmobranquios; UABCS; Carretera al sur km 105, La Paz, \\ $B C S$, Mexico
}

\begin{abstract}
The aim of this work was the description of fetal mummification in silky shark. During July of 2001 in Santa Maria fishing camp, Gulf of California Mexico, fourteen pregnant female of silky sharks were captured. In all of them the embryos were found to be dehydrated. However, total observations were possible in only two litters. Six embryos in each analyzed litters were found. All the embryos were mummified, complete and without maceration. Because the litters were totally mummificated in several females, it was suggested that fetal mummification was produced by the environmental condition.
\end{abstract}

Key words: Fetal mummification, Carcharhinus falciformis, Carcharinidae

\section{INTRODUCTION}

Embryonic pathology is very complex. Its study has been focused on mammals, mainly in humans and domestic animals. Embryonic pathology can produce fetal death, which affects demographic parameters like fecundity. Therefore, the embryonic losses influence the sustainability of the exploited population (Jonker, 2004), like some shark populations.

A mummified fetus is a dead fetus with no fluid cavities. The fetal mummification occurs when bacteria are not present and the fetus is maintained in the uterus where it undergoes slow decomposition and dehydration (Buergelt 2003).

Fetal mummification has been frequently reported *in mammals, but it has been found in only five species of shark. Springer (1960) reported two fetal mummies in the sandbar shark (Carcharhinus plumbeus). Clark and von Schmidt (1965) found

\footnotetext{
* Author for correspondence
}

one fetal mummy of the Mustelus norrissi, two fetal mummies of sandbar shark (C. plumbeus), one fetal mummy of the dusky shark (Carcharhinus obscurus), and one fetal mummy of the tiger shark (Galeocerdo cuvier). Randall (1977) reported one fetal mummy of the white tip reef shark (Trianodon obesus). Rosa-Molinar and Williams (1983) reported ten fetal mummies of sandbar shark (C. plumbeus). Nevertheless, in most cases, just one or two embryos per littler were mummified. Moreover, mummification factors have not been reported or discussed. In the present report the possible causes are discussed.

\section{MATERIALS AND METHOD}

During July 2001, in the artisanal fishing of Santa Maria fishing camp, (near Santa Rosalia, Baja California Sur, Mexico $27^{\circ} 20^{\prime} 15^{\prime}$ 'N and $112^{\circ} 15^{\prime} 47^{\prime}$ 'W), twenty one silky sharks (Carcharinus falciformis) were captured. The 
catches included fourteen pregnant females, which were measured (total length TL) and dissected. When were possible, the sex and total length of the embryos were determined.

\section{RESULTS}

Total lengths of pregnant females ranged from 183 to $209 \mathrm{~cm}$. All these females were apparently healthy. However, in all the litters, the placentas and embryos were fully dehydrated. All the fetuses were complete and were not macerated (Fig 1).

Nevertheless, the fishermen permitted neither the collection nor the analysis of all the litters. Complete analysis was possible only in two females. Six mummified fetuses were found in each litter, and three embryos in each uterus. In first female's embryos total lengths were between 35 and $41 \mathrm{~cm}$, and in the second, they were between 30 and $37 \mathrm{~cm}$, the sex proportion in both were one male per female (Table 1).

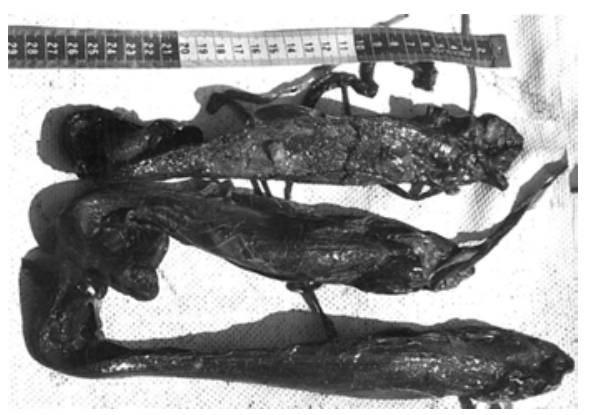

Figure 1 - Mummified embryos of silky shark (Carcharhinus flaciformis)

Table 1 - Mummified embryos, sex and total length, for mother and utero

\begin{tabular}{ccccc}
\hline & Embryo & Sex & Total Length $(\mathbf{c m})$ & Utero \\
\hline Mother 1 & & & 195.0 & \\
& 1 & male & 35.0 & Left \\
2 & male & 35.6 & Left \\
3 & female & 37.0 & Right \\
& 4 & male & 38.3 & Right \\
& 5 & female & 40.3 & Left \\
& 6 & female & 41.0 & Right \\
\hline Mother 2 & & 200.0 & Right \\
& 1 & male & 30.0 & Left \\
& 2 & male & 31.2 & Right \\
& 3 & male & 35.5 & Right \\
& 4 & female & 36.2 & Left \\
& 5 & female & 36.7 & Left \\
\hline
\end{tabular}

\section{DISCUSION}

The embryo death reasons have not been determined in shark fetal mummification reports. On the other hand, embryonic losses in mammals could be produced by infectious or non-infectious causes (Jonker, 2004). Infectious agents could be bacteria (Kirkbridge, 1993), protozoos (Anderson et al, 2000), fungi (Knudtson and Kirkbrige 1992) or viruses (Forman et al., 1977). Most of these 
agents produce maceration in the embryo's body (Jonker, 2004). Because no maceration was found in the fetuses, bacterial, protozoos or fungal infection could be discarded. However, viral infection was not discarded.

Non-infectious causes of fetal death include two type, maternal inherent conditions and environmental conditions (Jonker 2004). Maternal inherent causes include maternal malnutrition (Rhind, 2004), maternal stress (Silke, 2002), maternal hormonal imbalance (Gootwine, 2004), maternal illness (Risco et al., 1999), genetic factor (Meyer et al., 2001), immunologic incompatibility (Davies et al., 2004), deficient uterine environment or maternal age (Meyers and Varner 1991; Allen et al., 2002). Rosa-Molinar and Williams (1983) suggested that the insufficient uterine space prohibited placental implantation and caused the death in only one mummified embryo of $C$. plumbeus. However, in the two analyzed silky shark littlers, all embryos were dead and apparently the placentas were implanted in the uterus. Moreover, all pregnant females were apparently healthy.

On the other hand, most maternal inherent conditions affect only one female or a few females at a time in a population (Jonker 2004). But, environmental conditions like high temperature and pollutions produce fetal death in many females at a time in a population (Narendranath and Kiracofe, 1975; Jones et al., 1997). Because all embryos in fourteen females were founded mummified, it was supposed that the environmental conditions caused the fetal death. But no environmental analysis was possible.

Since all the observed litters were mummified, a strong diminish in the reproductive efficiency of the population could be produced. Therefore, this phenomenon has important effects in the conservation and management of the species.

\section{RESUMO}

A mumificação fetal é caracterizada pela desidatração de embriões mortos dentro do útero da mãe. A perda de embriões pode afetar a sustentabilidade da população explorada, tornando o estudo deste fenômeno de suma importância. Em Julho de 2001 quatorze femeas grávidas do tubarão lombo preto foram capituradas durante uma amostragem no campo pesqueiro de Santa Maria, Golfo de California, México. Todas as fêmeas capturadas apresentaram embriões mumificados. Infelizmente, observações detalhadas dos embriões foram possíveis em apenas duas fêmeas. Cada fêmea analizada apresentava seis embriões, todos completamente mumificados e sem maceração. Embriões completamente mumificados foram encontrados em muitas fêmeas, o que sugere que a mumificação fetal desses embriões pode ter sido causada por condições ambientais.

\section{REFERENCES}

Allen, W.; Wilsher, S.; Turnbull, C.; Stewart, F.; Ousey, J.; Rossdale, P. and Fowden, A. (2002), Influence of maternal size in placental, fetal and postnatal growth in the horse. I. Development in utero. Reproduction., 123, 445-453.

Anderson, M.; Andrianarivo, A. and Conrad, P. (2000), Neosporosis in cattle. Anim. Reprod. Sci., 60-61, 417431.

Buergelt, C. (2003), Pathology of reproductive system. http://www.vetmed.ufl.edu/path/teach/ vem5162 /reproductive/lec4.htm. University of Florida..

Clark, E. and von Schmidth, K. (1965) Sharks of the central Gulf coast of Florida. Bull. Mar. Sci, 15:(1), 13-83.

Davies, J.; Hill, J.; Edwars, J.; Schrick, F.; Fisher, P.; Eldridge, J. and Schlafer, D. (2004), Major histocompatibility antigen expression on the bovine placenta: its relationship to abnormal pregnancies and retained placenta. Anim. Reprod. Sci., 82-83, 267280.

Forman, A.; Lenghaus, C.; Hogg, G. and Hale, C. (1977), Association of a parvovirus with and outbreak of fetal death and mummification in pigs. Aust. Vet. J., 53:(7), 326-329.

Gootewine, E. (2004), Placental hormnones and fetalplacental development. Anim. Reprod. Sci., 82-83, 551-566.

Jonker, F. (2004), Fetal death: comparative aspect in large domestic animals. Anim. Reprod. Sci., 82-83, 415-430.

Jones, C.; Backlin, B.; Stoddart, R. and Dantzer, V. (1997), Environmental pollutants as aetiological agents in female reproductive pathology: placental glycan expression in normal and polychlorinated biphenyl (PCB) exposed mink (Mustela vison). Placenta., 18:(8), 689-699.

Kirkbridge, C. (1993), Bacterial agents detected in a 10year study of bovine abortions and stillbirths. J. Vet. Diagn. Invest., 4, 175-180.

Knudtson, W. and Kirkbridge, C. (1992), Fungi associated with bovine abortion in the northern plain states (USA). J. Vet. Diagn. Invest., 4, 181-185. 
Meyer, C.; Berger, P.; Koehler, K.; Thompson, J. and Sattler, C. (2001), Phenotypic trends in incidence of stillbirth for Holsteins in United States. J. Dairy Sci., 84, 515-523.

Mayer, P. and Varner, D. (1991), Abortion of a mummified fetus associated with short uterine body in a mare. J. Am. Vet. Med. Assoc., 198:(10), 17681770.

Narendranath, R. and Kiracofe, G. (1975), Effects of heat stress in tats. II, Factor (s) responsible for reduced embryonic and/or fetal survival perentage. Ind. J. Physiol. Pharma., 19:(3), 140-145.

Randall, J. (1977), Contribution of the biology of the whitetip reef shark (Trianodon obesus). Pacific Sci., 31(2):143-164.

Rhind, S. (2004), Effects of maternal nutrition on fetal and neonatal reproductive development and function. Anim. Reprod. Sci.,. 82-83, 169-181.
Risco, C.; Donovan, G. and Hernandez, J. (1999), Clinical mastitis associated with abortion in dairy cows. J. Dairy Sci., 82, 1684-1689.

Rosa-Molinar, E. and Williams, C. (1983), Fetal mummification in the Sandbar shark. Carcharinus plumbeus. J. Wildl. Dis., 19:(2), 156-258.

Silke, M.; Diskin, M.; Kenny, D.; Bolan, M.; Dillon, P.; Mee J. and Sreenan, J. (2002), Extent, pattern and factors associated with late empbryonic loss in dairy cows. Anim. Reprod.Sci., 71, 1-12.

Springer, S. (1960), Natural history of the sandbar shark Eulamia milberti. Fishe. Bull., 178:(61),1-38.

Received: June 13, 2005 Revised: March 03, 2006; Accepted: August 22, 2007 